\title{
Foreign body aspiration as a cause of recurrent pneumonia - case report
}

\author{
Aspiracja ciała obcego jako przyczyna nawracających zapaleń płuc - opis \\ przypadku
}

\author{
Kamil Piotr Janeczek ${ }^{1, A-B, D-F} \oplus$, Faustyna Piędel ${ }^{2, A-B, D, F} \oplus$, Agata Rocka ${ }^{2, A-B, D, F} \oplus$, \\ Agnieszka Grygiel ${ }^{2, A-B, D, F}{ }^{\oplus}$, Patryk Jasielski ${ }^{2, A-B, D, F}{ }^{,}$, Andrzej Emeryk ${ }^{1, A-B, D-F} \oplus$ \\ ${ }^{1}$ Department of Lung Diseases and Paediatric Rheumatology, II Department of Paediatrics, Medical University, Lublin, \\ Poland \\ ${ }^{2}$ Student Research Group at the Clinic of Lung Diseases and Paediatric Rheumatology, Medical University, Lublin, Poland \\ $A$ - Research concept and design, B - Collection and/or assembly of data, C - Data analysis and interpretation, \\ $D$ - Writing the article, $E$ - Critical revision of the article, $F$ - Final approval of article
}

\begin{abstract}
Janeczek KP, Piędel F, Rocka A, Grygiel A, Jasielski P, Emeryk A. Foreign body aspiration as a cause of recurrent pneumonia - case report.
\end{abstract} Med Og Nauk Zdr. 2020; 26(2): 186-189. doi: 10.26444/monz/122246

\section{Abstract}

Foreign body aspiration (FBA) is a life-threatening clinical condition, usually requiring immediate intervention involving the removal of a foreign body from the airways during bronchoscopy. Relevant history taking is a very important element in the diagnosis of FBA. Lack of information about the child's choking episode may delay making the correct diagnosis, and increase the risk of long-term complications of foreign body retention in the airways, including recurrent pneumonia. The case is presented of a 13-year-old boy diagnosed with pneumonia three times in four months. FBA was diagnosed after performing additional laboratory tests, imaging tests, and repeated history taking from the boy. The case report highlights the need for FBA suspicion if symptoms of pneumonia recur or persist despite proper treatment, even if insufficient evidence of FBA is provided in the initial interview.

\section{Key words}

foreign body aspiration, recurrent pneumonia, children, anamnesis

\section{Streszczenie}

Aspiracja ciała obcego (ang. foreign body aspiration, FBA) to zagrażający życiu stan kliniczny, wymagający zazwyczaj natychmiastowej interwencji, polegającej na usunięciu ciała obcego z dróg oddechowych podczas bronchoskopii. Bardzo ważnym elementem $w$ diagnostyce FBA jest prawidłowo zebrany wywiad z pacjentem oraz jego rodzicami, na podstawie którego można wysunąć podejrzenie aspiracji. Brak informacji na temat epizodu krztuszenia się dziecka w wywiadzie może wpływać na opóźnienie postawienia prawidłowej diagnozy i tym samym zwiększać ryzyko powikłań długotrwałego zalegania ciała obcego w drogach oddechowych, takich jak nawracające zapalenia płuc. Prezentujemy przypadek 13-letniego chłopca, u którego w ciągu czterech miesięcy trzykrotnie rozpoznawano zapalenie płuc. Po wykonaniu dodatkowych badań laboratoryjnych, obrazowych oraz ponownym zebraniu wywiadu z chłopcem rozpoznano FBA. Przedstawiony opis przypadku podkreśla potrzebę podejrzewania FBA jeśli objawy zapalenia płuc nawracają lub utrzymują się pomimo stosowania prawidłowego leczenia, nawet jeśli brak wystarczających dowodów na FBA we wstępnym badaniu podmiotowym.

\section{Słowa kluczowe}

aspiracja ciała obcego, nawracające zapalenie płuc, dzieci, wywiad lekarski

\section{INTRODUCTION}

Foreign body aspiration (FBA) is a life-threatening clinical condition that most often affects children under three years of age [1]. Most patients require immediate intervention involving the removal of a foreign body during bronchoscopy. Sometimes, however, the time that elapses between the aspiration of a foreign body and the time it is removed from the respiratory tract is as long as several days, or even several

Address for correspondence: Kamil Piotr Janeczek, Department of Lung Diseases and Paediatric Rheumatology, II Department of Paediatrics, Medical University, Lublin, Poland

E-mail: kamil.6@op.pl

Received: 15.03.2020; accepted: 11.05.2020; first published: 08.06.2020 months. This usually concerns older children, as many of them fail to provide a history of choking during initial evaluation [2]. Delay in diagnosis is associated with increased morbidity, especially concerning respiratory infections such as upper respiratory tract infection or recurrent pneumonia (at least two pneumonia episodes in a one-year period, or at least three during a lifetime) [3].

This study presents the case of a 13-year-old boy with recurrent episodes of pneumonia caused by the presence of a foreign body in the airways for more than four months. The authors obtained the written consent from patient's guardians for this case report. 


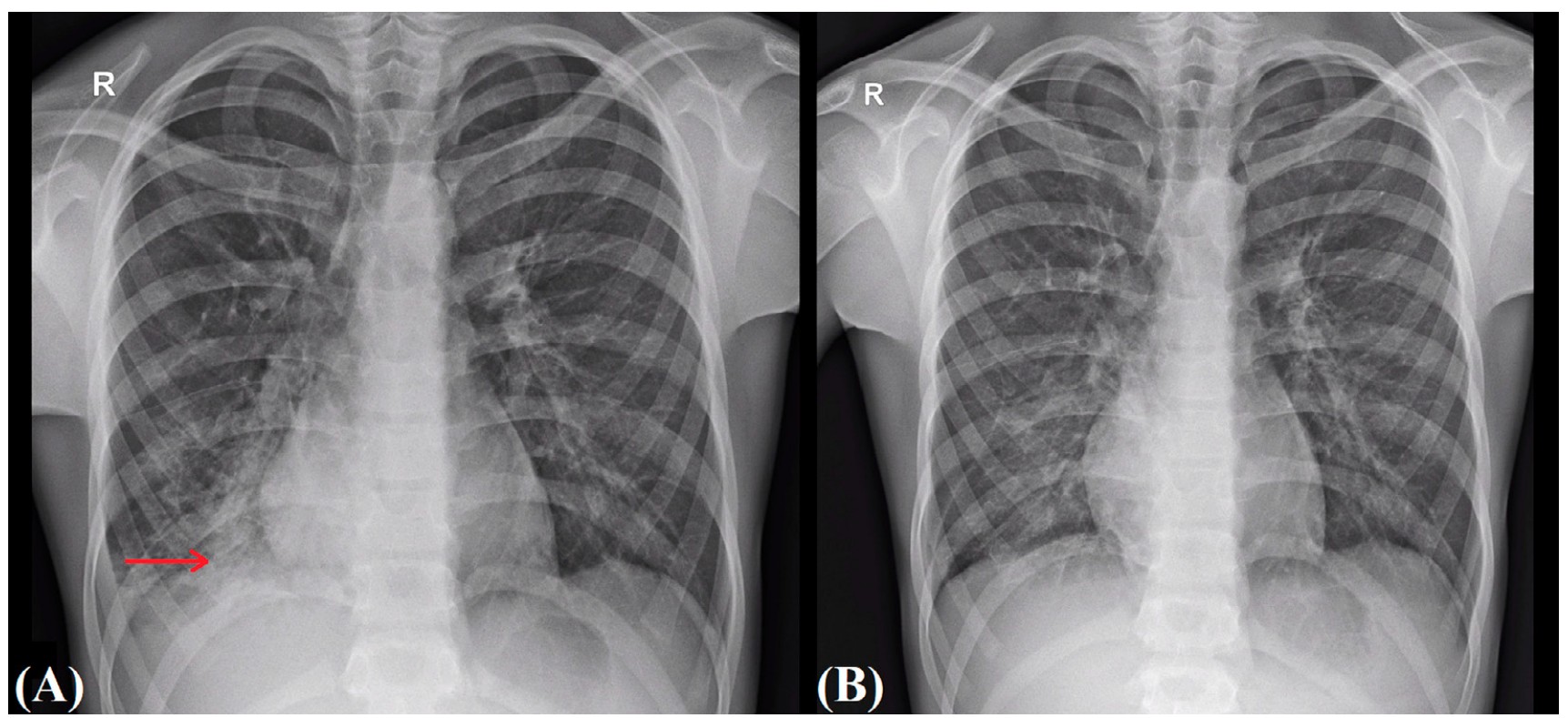

Figure 1. Chest X-ray. (A) Chest X-ray performed during the first episode of pneumonia - inflammatory and some atelectasis lesion in right lower lobe (red arrow) with some lung over-inflation on left side. (B) Follow-up chest X-ray after 2 weeks of treatment - regression of inflammatory changes

\section{CASE REPORT}

A 13 -year-old boy was admitted to the Pulmonology Clinic for diagnosis of chronic cough and recurrent pneumonia. In the last four months, the boy suffered from pneumonia three times. Antibiotics were used each time with good treatment effects (Fig. 1). The child had suffered from chronic cough since the first diagnosis of pneumonia - previously, the boy had been healthy, and only occasionally suffered from colds. Perinatal history was unencumbered. Interview and family history for allergic diseases was negative. The child was subjected to vaccination in accordance with the Polish immunization schedule. However, he was not vaccinated against pneumococci.

At the time of admission to hospital, the patient was in a good general condition, with efficient respiratory and circulatory systems, normal body temperature, with saturation of $98 \%$. Physical examination showed a steady heart rate of $80 / \mathrm{min}, 16$ breaths per minute. The auscultation test revealed decreased lung sounds at the base of the right lung, single wheezes and rhonchi. The remaining elements of physical examination were normal for age. Laboratory testing excluded infection with Mycoplasma pneumoniae, Chlamydia pneumoniae, Legionella pneumophila, Mycobacterium tuberculosis, and deficiencies in cellular and humoral immunity. Spirometry showed obstructive ventilator defect without improvement after bronchodilator. Thoracic computed tomography revealed annular shade in the intermediate bronchus of the right lung (Fig. 2).

Based on the symptoms described above and the results of additional tests, FBA was suspected and it was decided to deepen the interview with the patient and his parents. The mother strongly denied the possibility of foreign body aspiration, while the boy remembered that four months ago at school, while he was holding a pen in the mouth ending with a rubber eraser, he had an attack of strong coughing, after which the eraser 'went missing'. As a result, on the same day rigid bronchoscopy was performed and the foreign body

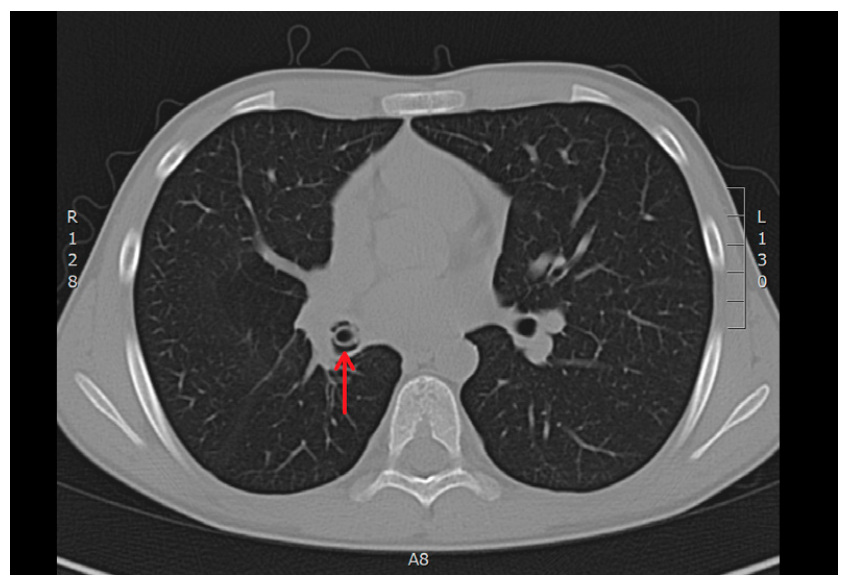

Figure 2. Thoracic computed tomography revealing annular shade in the intermediate bronchus of the right lung (red arrow)

removed from the intermediate right lung bronchi (Fig. 3). Today, the child is in good condition, asymptomatic and without further symptoms of pneumonia.

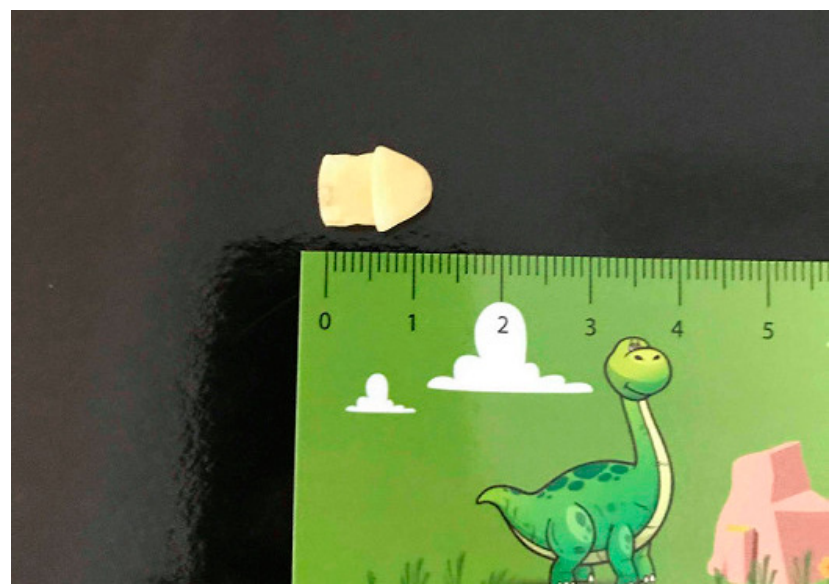

Figure 3. Foreign body (eraser) removed from the intermediate right lung bronchi 


\section{DISCUSSION}

FBA is a life-threatening clinical condition often requiring immediate medical intervention, which most often concerns children under three years of age. In the case of a foreign body completely closing the light of the larynx or trachea, the child may suddenly die. A foreign body can be any small object accidentally found by a child, most often it is a nut (peanut, hazelnut) $[1,4,5]$. For anatomic reasons, the foreign body most often locates in right main bronchi. The right bronchi is an extension of the trachea, it runs more vertically, it is wider and shorter compared to the left bronchi $[6,7]$.

Clinical presentation of FBA is variable, ranging from a clinically asymptomatic state to the state of respiratory failure seeking urgent intervention [8]. Symptoms of aspiration of a foreign body into the airways usually occur in three stages. Immediately after aspiration, a period of violent symptoms is observed, the severity of which depends on many factors, including: size, shape of the foreign body, and its location in the airways. These symptoms include: choking, coughing, stridor, shortness of breath and cyanosis. Even if the foreign body is not expectorated, these symptoms can disappear. However, after a latency period, symptoms of respiratory tract infection, wheezing, and sometimes haemoptysis appear. As shown by the study, the most common symptom of FBA is cough, and the most specific is the history of choking [5, $8]$. It should be remembered that $5-25 \%$ of patients do not present any symptoms associated with FBA [9].

Finding localized changes in physical examination and in imaging (chest X-ray, chest CT) facilitates the diagnosis of FBA. The lung auscultation usually revealed decreased lung sounds, wheezing and crepitation. In $25 \%$ of cases, no auscultatory changes are detected. The sensitivity and specificity of lung auscultation in diagnosing FBA was assessed at $82 \%$ and $50 \%$, respectively [9]. Most foreign bodies in children are radiolucent; however, in chest radiographs, indirect evidence for the presence of a foreign body in the airways, such as hyperinflation, atelectasis or consolidation, should be sought. It should be remembered that the correct chest X-ray does not exclude the possibility of FBA.

Previous studies have shown that thoracic computed tomography (CT) has higher specificity and sensitivity than chest X-ray in the diagnosis of FBA $[6,10]$. CT may allow for a more accurate assessment of the location of the foreign body, determine to what extent the foreign body obstructs the airway, and may identify related complications [11]. However, as in the case of chest X-rays, the physical properties of inhaled materials limit the ability of CT to detect disease [12]. A radiolucent foreign body that remains in the airways for a long time can be seen in radiological studies due to the consequences of the inflammatory process in the vicinity of the foreign body $[9,13]$.

Undoubtedly the most important element in the diagnosis of FBA is the interview with the patient and his/her carers. As mentioned above, the most important factor for diagnosis is the presence of aspiration history and initial history of choking $[2,4]$. Usually it is an acute episode in which the family suspects that the child has aspirated a foreign body. However, it should be remembered that the lack of mention of such an episode in the interview does not allow for its exclusion because parents are often not present at such an event. This usually applies to older children, as many of them fail to provide a history of choking during initial evaluation.
Girardi et al. showed that nearly $33 \%$ of children during the physical examination initially negated the fact of choking in the past, and it was elicited only upon follow-up questioning [14]. As reported by Paksu et al., neither clinical symptoms nor changes in chest radiograph are as sensitive and specific as a positive history [5].

Removal of the foreign body soon after aspiration $(<24 \mathrm{~h})$ allows complete cure and leaves no changes in the respiratory system [15]. Delay in the diagnosis of FBA and the performance of rigid bronchoscopy (the gold standard procedure for FBA) may have various complications, such as: dyspnea, recurrent respiratory tract infection, pneumothorax, pneumopericardium, pneumomediastinum, atelectasis, obstructive emphysema, asphyxia and even death [16]. Prolonged retention of a foreign body disturbs mucociliary clearance, causing accumulation of secretions in the airways distal to the foreign body. The retained secretion is colonized by bacteria gaining access with inhaled air or present on the foreign body, as a result of which inflammation develops. The factors that increases the risk of pneumonia in the course of FBA include: age under two years, plant foreign body, non-smooth foreign body, and long term incarceration $(>7$ days) [6]. In view of the above, recurrent pneumonia should suggest the possibility of FBA, especially when symptoms persist despite appropriate treatment for pneumonia, or if these are recurrent, pneumonia occurring within a short period of time $[17,18]$.

It is worth noting that with the prolongation of the retention time of the foreign body in the airways, the risk of complications of bronchoscopy increases, e.g. bronchial bleeding, pneumothorax, pneumomediastinum, laryngeal oedema, bronchial stenosis, tracheobronchial fistulae, and even death of the patient [15].This results from the consequences of the inflammatory process in the respiratory system in the form of mucosal oedema and granulations. Chen and Zhang showed that in the group of patients diagnosed with FBA 24 hours after the episode of choking, had a significantly longer operation time and hospitalization time than the non-delayed treatment group (18 minutes vs. 10 minutes, $\mathrm{p}<0.01 ; 4$ days vs. 3 days; $\mathrm{p}<0.01$, respectively) [18]. Thus, early rigid bronchoscopy within the first 24 hours is recommended to avoid complications. In the case of the 13-year-old boy in the presented case report, the foreign body was removed from the respiratory tract four months after its aspiration.

One of the important elements of the diagnostic procedure is undoubtedly a properly conducted interview with the child and his/her guardians. The most important factor for correct diagnosis of FBA is the presence of aspiration history, the lack of which can lead to an incorrect diagnoses, delays in making the right diagnosis, and thus complications resulting from the prolongation of the retention time of the foreign body in the airways. FBA should be suspected if the symptoms of pneumonia recur or persist despite proper treatment, even if there is insufficient evidence of FBA in the initial interview.

\section{Conflicts of Interest}

The authors declare no conflict of interest.

\section{Source of funding}

No external funding was received for this study. 


\section{REFERENCES}

1. Dorterler ME, Kocaman OH, Gunendi T, Boleken ME. A single-center experience of pediatric foreign-body aspiration: A retrospective 4-year case series. Lung India. 2019; 36(3): 202-206. https://doi.org/10.4103/ lungindia.lungindia_69_18

2.Dhungana A, Thapa A. Flexible Bronchoscopic Removal of a Forgotten Intrabronchial Foreign Body. J Nepal Health Res Counc. 2019; 16(41): 470-472. https://doi.org/10.33314/jnhrc.v16i41.1260

3. Owayed AF, Campbell DM, Wang EE. Underlying causes of recurrent pneumonia in children. Arch Pediatr Adolesc Med. 2000; 154(2): 190-194. https://doi.org/10.1001/archpedi.154.2.190

4. Cui Y, Cui X, Yu T, Zhu Z, Wang X. Importance of patient history in diagnosis of foreign body aspiration in children: Two case reports. Medicine (Baltimore). 2019; 98(17): e15326. https://doi.org/10.1097/ MD.0000000000015326

5. Paksu S, Paksu MS, Kilic M, Guner SN, Baysal K, Sancak R, et al. Foreign body aspiration in childhood: evaluation of diagnostic parameters Pediatr Emerg Care. 2012; 28(3): 259-264. https://doi.org/10.1097/ PEC.0b013e3182494eb6

6.Zhong B, Sun SL, Du JT, Deng D, Liu F, Liu YF, et al. Risk factors for lower respiratory tract infection in children with tracheobronchial foreign body aspiration. Medicine (Baltimore). 2019; 98(10): e14655. https://doi.org/10.1097/MD.0000000000014655

7. Sultan TA, van As AB. Review of tracheobronchial foreign body aspiration in the South African paediatric age group. J Thorac Dis. 2016; 8(12): 3787-3796. https://doi.org/10.21037/jtd.2016.12.90

8. Acharya K. Rigid Bronchoscopy in Airway Foreign Bodies: Value of the Clinical and Radiological Signs. Int Arch Otorhinolaryngol. 2016; 20(3): 196-201. https://doi.org/10.1055/s-0036-1584293
9. Álvarez-Buylla BM, Morán AM, Paredes IA, Vidal MJ. Bronchoscopy in Children With Foreign Body Aspiration. Acta Otorrinolaringol Esp. 2008; 59: 183-189. https://doi.org/10.1016/S2173-5735(08)70218-7 10. Pitiot V, Grall M, Ploin D, Truy E, Ayari Khalfallah S. The use of CTscan in foreign body aspiration in children: A 6 years' experience. Int J Pediatr Otorhinolaryngol. 2017; 102: 169-173. https://doi.org/10.1016/j. ijporl.2017.08.036

11. Xu Y, Feng RL, Jiang L, Ren HB, Li Q. Correlative factors for the location of tracheobronchial foreign bodies in infants and children. J Thorac Dis. 2018; 10(2): 1037-1042. https://doi.org/10.21037/jtd.2018.01.121

12. Lin L, Lv L, Wang Y, Zha X, Tang F, Liu X. The clinical features of foreign body aspiration into the lower airway in geriatric patients. Clin Interv Aging. 2014; 9: 1613-1618. https://doi.org/10.2147/CIA.S70924

13. Martin A, van der Meer G, Blair D, Mahadevan M, Neeff M, Barber C, et al. Long-standing inhaled foreign bodies in children: Characteristics and outcome. Int J Pediatr Otorhinolaryngol. 2016; 90: 49-53. https:// doi.org/10.1016/j.ijporl.2016.08.018

14. Girardi G, Contador AM, Castro-Rodríguez JA. Two new radiological findings to improve the diagnosis of bronchial foreign-body aspiration in children. Pediatr Pulmonol. 2004; 38: 261-264. https://doi. org/10.1002/ppul.20065

15. Hajnal D, Kovács T. Foreign body aspiration of the lower airways in children - diagnosis in clinical practice. Orv Hetil. 2018; 159(51): 2162-2166. https://doi.org/10.1556/650.2018.31165

16. Mallick MS. Tracheobronchial foreign body aspiration in children: a continuing diagnostic challenge. Afr J Paediatr Surg. 2014; 11(3): 225-228. https://doi.org/10.4103/0189-6725.137330

17. Tatsanakanjanakorn W, Suetrong S. Do Times until Treatment for Foreign Body Aspiration Relate to Complications? Int J Otolaryngol. 2016; 2016: 2831614. https://doi.org/10.1155/2016/2831614

18. Chen X, Zhang C. Foreign body aspiration in children: Focus on the impact of delayed treatment. Int J Pediatr Otorhinolaryngol. 2017; 96: 111-115. https://doi.org/10.1016/j.ijporl.2017.03.013 